WSRC-STI-2008-00336

Rev. 0

\title{
MEASUREMENT OF WASTE LOADING IN SALTSTONE
}

\author{
J. R. Harbour and V. J. Williams
}

Savannah River National Laboratory

June 2008

Process Science and Engineering Savannah River National Laboratory Aiken, SC 29808

Prepared for the U.S. Department of Energy Under Contract Number DEAC09-96SR18500

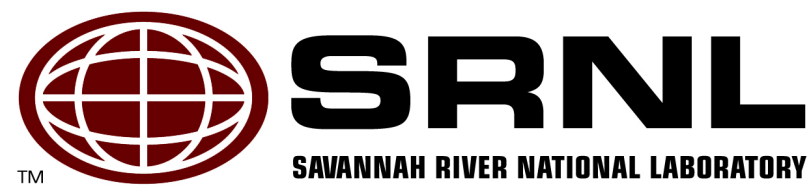




\section{DISCLAIMER}

This report was prepared by Washington Savannah River Company (WSRC) for the United States Department of Energy under Contract No. DE-AC09-96SR18500 and is an account of work performed under that contract. Neither the United States Department of Energy, nor WSRC, nor any of their employees makes any warranty, expressed or implied, or assumes any legal liability or responsibility for the accuracy, completeness, or usefulness, of any information, apparatus, or product or process disclosed herein or represents that its use will not infringe privately owned rights. Reference herein to any specific commercial product, process, or service by trademark, name, manufacturer or otherwise does not necessarily constitute or imply endorsement, recommendation, or favoring of same by WSRC or by the United States Government or any agency thereof. The views and opinions of the authors expressed herein do not necessarily state or reflect those of the United States Government or any agency thereof.

\section{Printed in the United States of America}

Prepared For

U.S. Department of Energy 
WSRC-STI-2008-00336

Rev. 0

Key Words: Premix

Water to premix ratio Density

Retention: Permanent

\title{
MEASUREMENT OF WASTE LOADING IN SALTSTONE
}

\author{
J. R. Harbour and V. J. Williams
}

Savannah River National Laboratory

June 2008

Process Science and Engineering

Savannah River National Laboratory

Aiken, SC 29808

Prepared for the U.S. Department of Energy Under Contract Number DEAC09-96SR18500

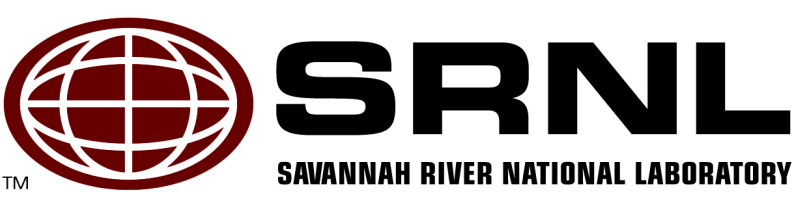




\section{REVIEWS AND APPROVALS}

\section{AUTHORS:}

J. R. Harbour, SRNL, Engineering Process Development

Date

V. J. Williams, SRNL, Engineering Process Development

Date

TECHNICAL REVIEWERS:

A. D. Cozzi, SRNL, Engineering Process Development

Date

\section{APPROVERS}

A. B. Barnes, SRNL, Manager, Engineering Process Development

Date

J. C. Griffin SRNL, Manager, E\&CPT Research Programs

Date

J. E. Occhipinti, Manger, Waste Solidification Engineering

Date 


\section{EXECUTIVE SUMMARY}

One of the goals of the Saltstone variability study is to identify the operational and compositional variables that control or influence the important processing and performance properties of Saltstone grout mixtures. One of those properties of importance is the Waste Loading (WL) of the decontaminated salt solution (DSS) in the Saltstone waste form. Waste loading is a measure of the amount of waste that can be incorporated within a waste form. The value of the Saltstone waste loading ultimately determines the number of vaults that will be required to disposition all of the DSS. In this report, the waste loading is defined as the volume in milliliters of DSS per liter of Saltstone waste form.

The two most important parameters that determine waste loading for Saltstone are water to cementitious material $(\mathrm{w} / \mathrm{cm})$ ratio and the cured grout density. Data are provided that show the dependence of waste loading on the $\mathrm{w} / \mathrm{cm}$ ratio for a fixed DSS composition using the current premix material (45 \% Blast Furnace Slag (BFS), $45 \%$ Fly Ash (FA) and $10 \%$ Ordinary Portland Cement (OPC)). The impact of cured grout density on waste loading was also demonstrated. Mixes (at $0.60 \mathrm{w} / \mathrm{cm}$ ) made with a Modular Caustic side extraction Unit (MCU) simulant and either OPC or BFS have higher cured grout densities than mixes made with premix and increase the WL to $709 \mathrm{~mL} / \mathrm{L}$ for the OPC mix and $689 \mathrm{~mL} / \mathrm{L}$ for the BFS mix versus the value of $653 \mathrm{~mL} / \mathrm{L}$ for MCU in premix at $0.60 \mathrm{w} / \mathrm{cm}$ ratio.

Bleed liquid reduces the waste loading and lowers the effective w/cm ratio of Saltstone. A method is presented (and will be used in future tasks) for correcting the waste loading and the $\mathrm{w} / \mathrm{cm}$ ratio of the as-batched mixes in those cases where bleed liquid is present. For example, the Deliquification, Dissolution and Adjustment (DDA) mix at an as-batched $0.60 \mathrm{w} / \mathrm{cm}$ ratio, when corrected for $\%$ bleed, gives a mix with a $0.55 \mathrm{w} / \mathrm{cm}$ ratio and a WL that has been reduced from 662 to $625 \mathrm{~mL} / \mathrm{L}$.

An example is provided that demonstrated the quantitative impact of WL on the number of cells (each Saltstone vault contains two cells) required to disposition all of the $\sim 100$ million gallons of DSS available in the tanks. This calculation revealed that the number of cells required over the range of 0.48 to $0.62 \mathrm{w} / \mathrm{cm}$ ratio (equivalent to a $\mathrm{WL}$ range of 591 to $666 \mathrm{~mL} / \mathrm{L}$ ) varies from 65 to 57 cells ( 33 to 29 vaults). The intent of this oversimplified example was to show the range of variation in vaults expected due to $\mathrm{w} / \mathrm{cm}$ ratio rather than to estimate the actual number of vaults required.

There is a tradeoff between the waste loading and the processing and performance properties of Saltstone. The performance properties improve in general as the $\mathrm{w} / \mathrm{cm}$ ratio decreases whereas the waste loading is reduced at lower $\mathrm{w} / \mathrm{cm}$ ratios resulting in a larger number of Saltstone vaults. The final performance and processing requirements of Saltstone will determine the maximum waste loading achievable. 
TABLE OF CONTENTS

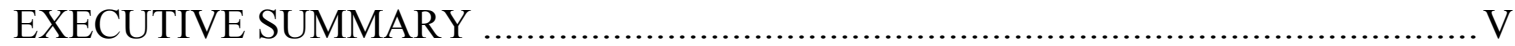

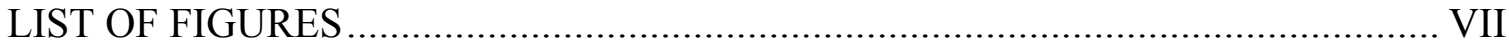

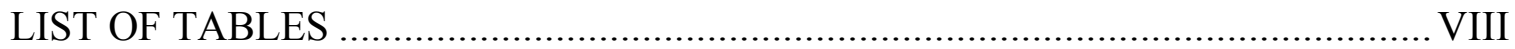

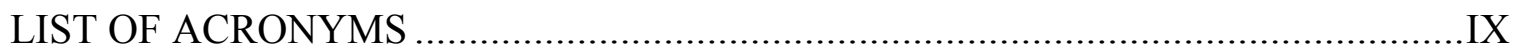

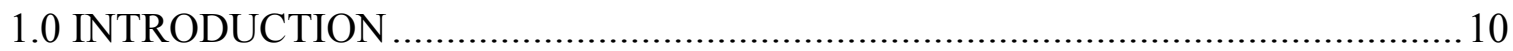

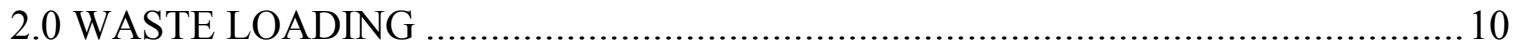

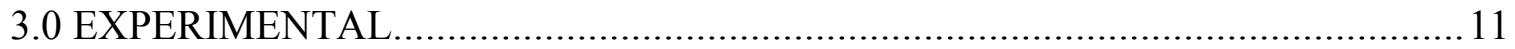

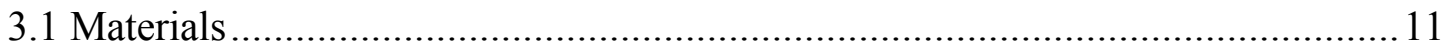

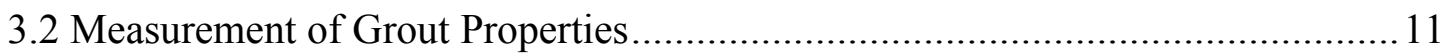

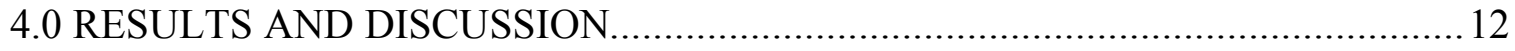

4.1 Waste Loading for DDA, MCU and SWPF Grouts at $0.60 \mathrm{w} / \mathrm{pm}$ Ratio ................12

4.2 Waste Loading as a Function of w/cm Ratio for MCU Mixes.............................13

4.3 Waste Loading as a Function of Premix Composition for MCU Mixes................16

4.4 Impact of Waste Loading on Number of Vaults................................................ 17

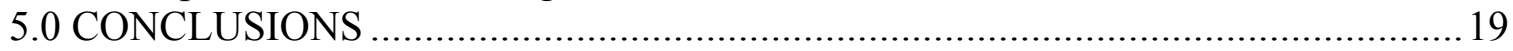

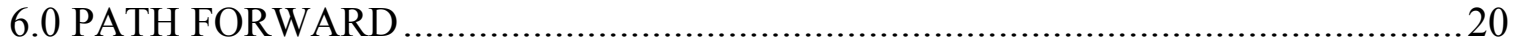

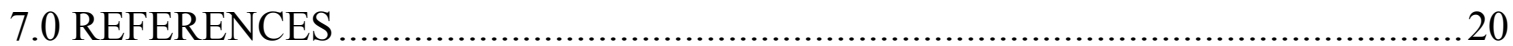




\section{LIST OF FIGURES}

Figure 4-1 Waste loading as a function of w/cm ratio for MCU and premix grouts............ 14

Figure 4-2 Porosity as a function of waste loading for MCU and premix grouts.............. 14

Figure 4-3 Normalized heat of hydration ( $\mathrm{J} / \mathrm{g}$ of premix) as a function of $\mathrm{w} / \mathrm{cm}$ ratio for MCU

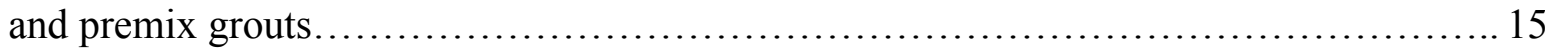

Figure 4-4 Normalized heat of hydration ( $\mathrm{J} / \mathrm{gram}$ of grout) as a function of $\mathrm{w} / \mathrm{cm}$ ratio for MCU

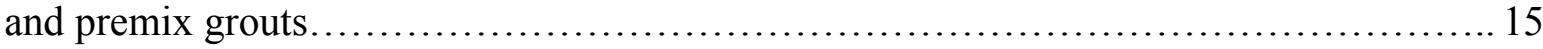

Figure 4-5 Normalized heats of hydration as a function of waste loading for MCU and premix

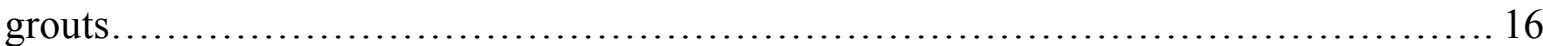

Figure 4-6 Schematic (not to scale) of current design for the next generation cells within the Saltstone vaults..................................................... 17

Figure 4-7 Number of cells required at the SDF as a function of waste loading for this example (the values next to the 4 points on the graph are the w/cm ratios for each mix)........ 


\section{LIST OF TABLES}

Table 3-1 Saltstone Cementitious Materials .................................................................... 11 Table 4-1 Uncorrected Waste Loadings (WL) for Mixes at a $0.60 \mathrm{w} / \mathrm{pm}$ Ratio. Values for WL in Mass Ratio and $\mathrm{g} / \mathrm{L}$ are also Provided for Reference .................................................. 12

Table 4-2 Corrected Waste Loadings (WL) and w/pm Ratios for Mixes with an As-Batched 0.60

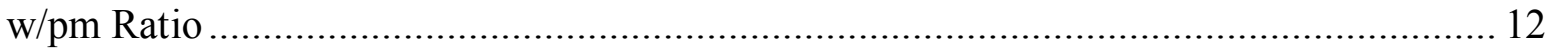

Table 4-3 WL as a Function of w/cm Ratio for MCU and Premix Mixes ............................... 13

Table 4-4 Waste Loading for MCU Mixes Batched Using OPC or BFS 


\section{LIST OF ACRONYMS}

\begin{tabular}{|l|l|}
\hline ACTL & Aiken County Technology Laboratory \\
\hline FA & Class F Fly Ash \\
\hline BFS & Blast Furnace Slag \\
\hline DDA & Deliquification, Dissolution and Adjustment \\
\hline DSS & Decontaminated Salt Solution \\
\hline MCU & Modular Caustic Side Solvent Extraction Unit \\
\hline OPC & Ordinary Portland Cement \\
\hline SDF & Saltstone Disposal Facility \\
\hline SRNL & Savannah River National Laboratory \\
\hline SRS & Savannah River Site \\
\hline SWPF & Salt Waste Processing Facility \\
\hline TR & Trial Run \\
\hline W/cm & Water to Cementitious Material Ratio \\
\hline w/pm & Water to Premix Ratio \\
\hline WL & Waste Loading \\
\hline WSRC & Washington Savannah River Company \\
\hline
\end{tabular}




\subsection{INTRODUCTION}

One of the goals of the Saltstone variability study is to identify the operational and compositional variables that control or influence the important processing and performance properties of Saltstone grout mixtures [1and 2]. One of those properties of importance is the waste loading of the decontaminated salt solution (DSS) in the Saltstone waste form at the Saltstone Disposal Facility (SDF). This property has taken on increased importance due to the ongoing effort at formulation development for improving the performance properties of Saltstone. In order to achieve improved performance, some of the grout formulations being considered will decrease the waste loading. Therefore, it is important to measure waste loading for all the mixes in order to have a better basis (which includes the reduction in waste loading) through which a new formulation (if required) can be selected.

This report presents a working definition of waste loading, identifies the variables which must be measured to calculate waste loading, identifies $\mathrm{w} / \mathrm{cm}$ ratio and cured grout density as the two variables that have the most effect on waste loading, and provides examples that show the magnitude of the changes in WL that can occur due to operational and compositional variation.

\subsection{WASTE LOADING}

The waste loading of a particular waste form is a quantitative measure of the amount of waste that can be incorporated into the final waste form. For Saltstone, the waste is defined as the decontaminated salt solution (DSS). The Saltstone waste form is a grout obtained by mixing the DSS with a mixture (referred to as premix) by weight of $45 \%$ BFS, $45 \%$ Class F FA, and $10 \%$ OPC. The waste loading depends significantly on the $\mathrm{w} / \mathrm{cm}$ ratio (or when premix is used on the water to premix (w/pm) ratio) defined by the formulation and the resulting cured grout density.

The waste loading (WL) on a volume basis is defined by Equation 1 .

$$
\mathrm{WL}=\text { volume of DSS/ volume of Saltstone }
$$

If the volume of DSS is in $\mathrm{mL}$ and the volume of Saltstone is in liters, then the units of WL are $\mathrm{mL}$ of DSS/L of Saltstone. In laboratory scale mixes, the mass of DSS can be measured directly and then divided by the density of the DSS to determine the volume of DSS and the volume of Saltstone waste form can be determined by measuring the mass of the cementitious materials and DSS used in the mix and independently measuring the cured grout density.

The following is an example of WL determination for an MCU simulant mixed with premix to produce a grout at $0.60 \mathrm{w} / \mathrm{pm}$ ratio. A mix containing 747.69 grams of MCU simulant (with a density of $1.261 \mathrm{~g} / \mathrm{mL}$ ) and 852.31 grams of premix will produce 1600 grams of grout. There are $511.39 \mathrm{~g}$ of water in 747.69 grams of MCU. The resulting mix has a $0.60 \mathrm{w} / \mathrm{pm}$ ratio. The cured grout density of this mix (measured by gas pycnometry) is $1.785 \mathrm{~g} / \mathrm{mL}$ with no bleed after 3 days. Therefore, there are $896.4 \mathrm{~mL}(1600 \mathrm{~g} / 1785 \mathrm{~g} / \mathrm{L})$ or $0.896 \mathrm{~L}$ of grout produced with this 
mix. The volume of MCU simulant is obtained by dividing the mass of MCU by the density (747.69 g / 1/261 g/mL) which equals $592.93 \mathrm{~mL}$. By Equation 1, the WL is then equal to $592.93 \mathrm{~mL}$ divided by $0.896 \mathrm{~L}$ of grout or $662 \mathrm{~mL} \mathrm{DDS} / \mathrm{L}$ of Saltstone. This waste loading calculation holds for a mix that has no bleed water and no insoluble solids. The impact of bleed and insoluble solids on WL will be addressed in Section 4.

\subsection{EXPERIMENTAL}

\subsection{Materials}

The cementitious materials were obtained from Saltstone in 5 gallon containers and are listed in Table 3-1. These materials were specified in a Washington Savannah River Company (WSRC) contract for Saltstone cementitious materials and arrived with the delivery of the cementitious materials to Saltstone. The materials were transferred to smaller plastic bottles at Aiken County Technical Laboratory (ACTL) and tightly sealed. Maintaining these materials in a tightly sealed container limits the exposure of the materials to humid air. Table 3-1 also contains the wt $\%$ contribution of each material used to make the premix.

Table 3-1 Saltstone Cementitious Materials

\begin{tabular}{|c|c|c|c|}
\hline Material & Category & Vendor & Premix Blend (wt\%) \\
\hline Portland cement (OPC) & Type II & Holcim & 10 \\
\hline Blast Furnace slag (GGBFS) & Grade I or II & Holcim & 45 \\
\hline Fly ash (FA) & Class F & SEFA & 45 \\
\hline
\end{tabular}

The compositions of DDA, MCU and SWPF have been detailed elsewhere [2].

\subsection{Measurement of Grout Properties}

The methods used for the measurements of both fresh and cured grout properties have been discussed previously and were used for this report [2-5]. 


\subsection{RESULTS AND DISCUSSION}

\subsection{Waste Loading for DDA, MCU and SWPF Grouts at $0.60 \mathrm{w} / \mathrm{pm}$ Ratio}

The uncorrected waste loading of mixes made with the three baseline simulants and premix at the normal ratio ( $45 \% \mathrm{BFS}, 45 \% \mathrm{FA}$ and $10 \% \mathrm{OPC}$ ) at a w/pm ratio of 0.60 are presented in Table 4-1.

Table 4-1 Uncorrected Waste Loadings (WL) for Mixes at a $0.60 \mathrm{w} / \mathrm{pm}$ Ratio. Values for WL in Mass Ratio and $g / L$ are also Provided for Reference

\begin{tabular}{|c|c|c|c|c|c|c|}
\hline Simulant & Density & Simulant & Total & Mass Ratio & WL & WL \\
\hline type & $\mathrm{g} / \mathrm{mL}$ & $\mathrm{g}$ & $\mathrm{g}$ & & $\mathrm{g} / \mathrm{L}$ & $\mathrm{mL} / \mathrm{L}$ \\
\hline DDA & 1.78 & 2225 & 5100 & 0.44 & 777 & 662 \\
\hline MCU & 1.79 & 2382 & 5100 & 0.47 & 834 & 661 \\
\hline SWPF & 1.80 & 2335 & 5100 & 0.46 & 824 & 660 \\
\hline
\end{tabular}

These values are calculated independent of any bleed water that may be present. To correct for the presence of bleed water, it is necessary to reduce the amount of simulant and the total amount of grout that will be produced for a given batch and recalculate the WL.

For example, the bleed value for the DDA simulant at 1 day was 6.0 volume \%. This volume of bleed corresponds to a mass of simulant that must be subtracted from the simulant mass given in Table 4-1. In addition the total mass of grout produced must also be reduced by this mass of simulant. After performing these adjustments, the WL's and w/cm ratios were recalculated and are presented in Table 4-2. In the SDF, the bleed liquid will be recycled and included as part of subsequent batches of Saltstone.

Table 4-2 Corrected Waste Loadings (WL) and w/pm Ratios for Mixes with an As-Batched 0.60 w/pm Ratio

\begin{tabular}{|c|c|c|c|}
\hline Type & WL & Bleed & w/cm \\
\hline & $\mathrm{mL} / \mathrm{L}$ & Volume $\%$ & \\
\hline DDA & 625 & 6.0 & 0.548 \\
\hline MCU & 653 & 1.5 & 0.586 \\
\hline SWPF & 645 & 2.6 & 0.575 \\
\hline
\end{tabular}

The DDA based mix had the greatest amount of bleed volume and consequently, the greatest impact on the waste loading as evidenced by the reduction of WL from $662 \mathrm{~mL} / \mathrm{L}$ to $625 \mathrm{~mL} / \mathrm{L}$. On the other hand, the MCU mix had the smallest amount of bleed liquid and smallest change in the WL. The presence of bleed liquid leads to a lower $\mathrm{w} / \mathrm{cm}$ ratio than expected from the asbatched formulation. For example, with the DDA batch, the $\mathrm{w} / \mathrm{cm}$ ratio was reduced from the as batched value of 0.60 to a value of 0.548 after correction for bleed liquid. 
The evolution of bleed water from a grout or concrete is a complex time dependent process. Normally, the approach taken at SRNL is to measure the \% bleed at 1 day (and sometime 3 days) in sealed containers. For this study, the amounts of bleed liquid used to correct the waste loadings in Table 4-2 were those measured after one day. In some cases, the bleed will diminish with time as it is reabsorbed by the mix. Therefore, in the presence of a bleed liquid collection system, the amount of bleed may be greater than the amount measured after one day.

If insoluble solids are present in the DSS, then this amount of solids must be included in the calculation of the WL. For example a DSS with $1 \mathrm{wt} \%$ insoluble solids, the calculation of waste loading must include the mass of the DSS slurry in the numerator of Equation 1. Measurement of the cured grout density will take into account any change in the denominator of Equation 1 due to the insoluble solids. Additional research will be required to determine the quantitative impact of insoluble solids.

\subsection{Waste Loading as a Function of w/cm Ratio for MCU Mixes}

The waste loading depends on the $\mathrm{w} / \mathrm{cm}$ ratio as demonstrated for the baseline MCU simulant mixed with premix by the data in Table 4-3. In this case, there was no discernable bleed for any of the samples and therefore, no bleed correction to the WL was required. The range of WL measured for these mixes was 591 to $666 \mathrm{~mL} / \mathrm{L}$. The nominal value for WL at $0.60 \mathrm{w} / \mathrm{cm}$ ratio is $653 \mathrm{~mL} / \mathrm{L}$. Using this nominal value, the WL had decreased by $\sim 10 \%$ for a reduction to a 0.48 $\mathrm{w} / \mathrm{cm}$ ratio. The porosity values for each mix are included in Table 4-3 to show that lower w/ $\mathrm{cm}$ ratios result in lower porosities and to point out that performance properties in general improve as the $\mathrm{w} / \mathrm{cm}$ ratio is decreased.

Table 4-3 WL as a Function of w/cm Ratio for MCU and Premix Mixes

\begin{tabular}{|c|c|c|c|c|c|c|c|}
\hline & Grout Density & simulant & Total & Mass Ratio & w/cm & Porosity & WL \\
\hline & $\mathrm{g} / \mathrm{mL}$ & $\mathrm{g}$ & $\mathrm{g}$ & & & volume $\%$ & $\mathrm{~mL} / \mathrm{L}$ \\
\hline MCU & 1.81 & 164.8 & 400 & 0.41 & 0.48 & 56.0 & 591 \\
\hline MCU & 1.81 & 174.1 & 400 & 0.44 & 0.53 & 59.5 & 624 \\
\hline MCU & 1.79 & 182.7 & 400 & 0.46 & 0.58 & 61.5 & 648 \\
\hline MCU & 1.76 & 190.7 & 400 & 0.48 & 0.62 & 63.5 & 666 \\
\hline
\end{tabular}

Figure 4-1 shows this dependence of waste loading on the w/cm ratio for the MCU and premix grouts. It is evident from this figure that the waste loading decreases as the $\mathrm{w} / \mathrm{cm}$ ratio decreases. The impact of WL on the number of vaults required for all of the DSS is presented in Section 4.4. Figure 4.2 shows the dependence of the porosity on the waste loading. 


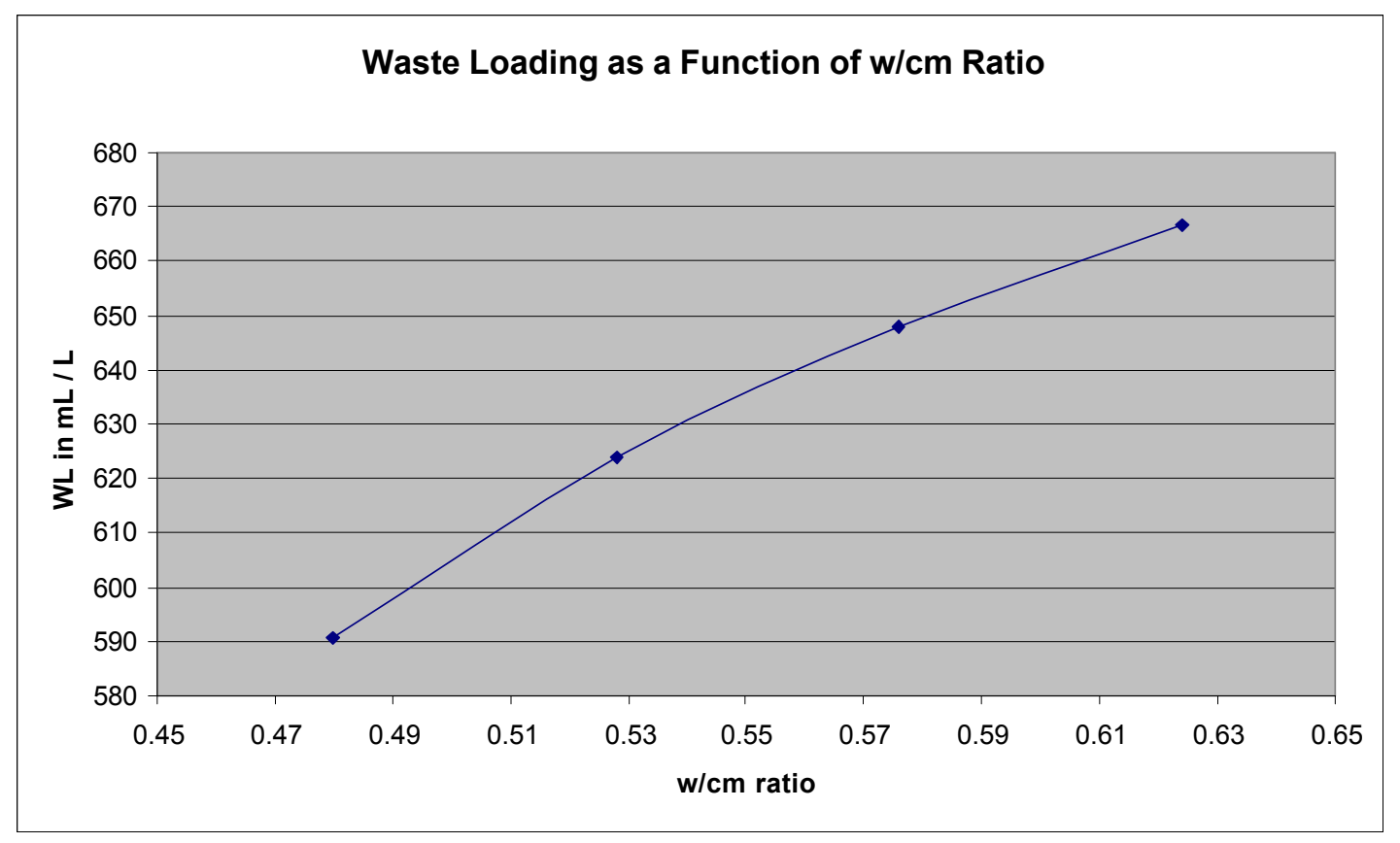

Figure 4-1 Waste loading as a function of $\mathrm{w} / \mathrm{cm}$ ratio for $\mathrm{MCU}$ and premix grouts

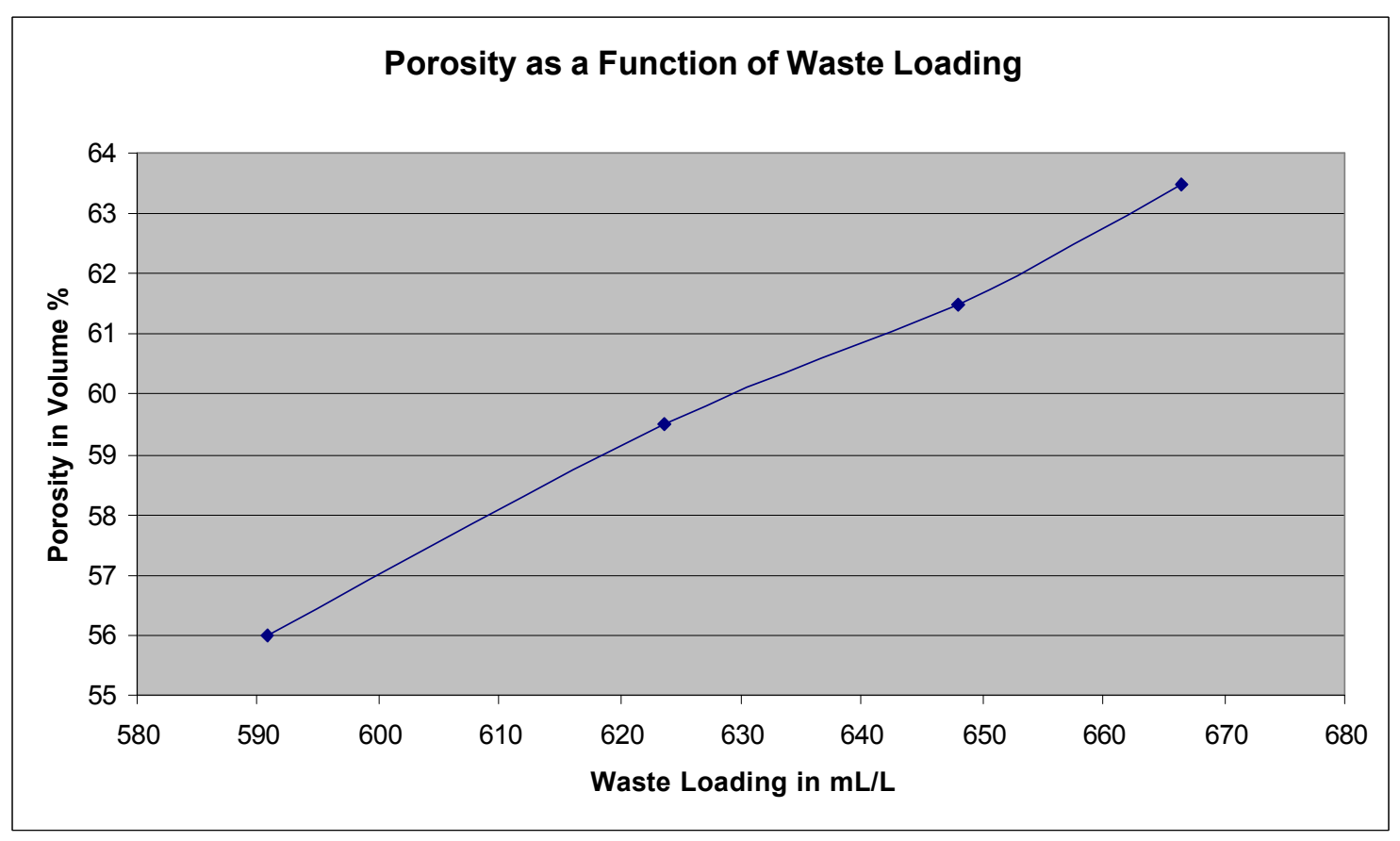

Figure 4-2 Porosity as a function of waste loading for MCU and premix grouts 
Figures 4-3 and 4-4 show the heat of hydration for these $4 \mathrm{MCU}$ and premix grouts normalized in Figure 4-3 to the grams of premix and in Figure 4-4 to the grams of grout.

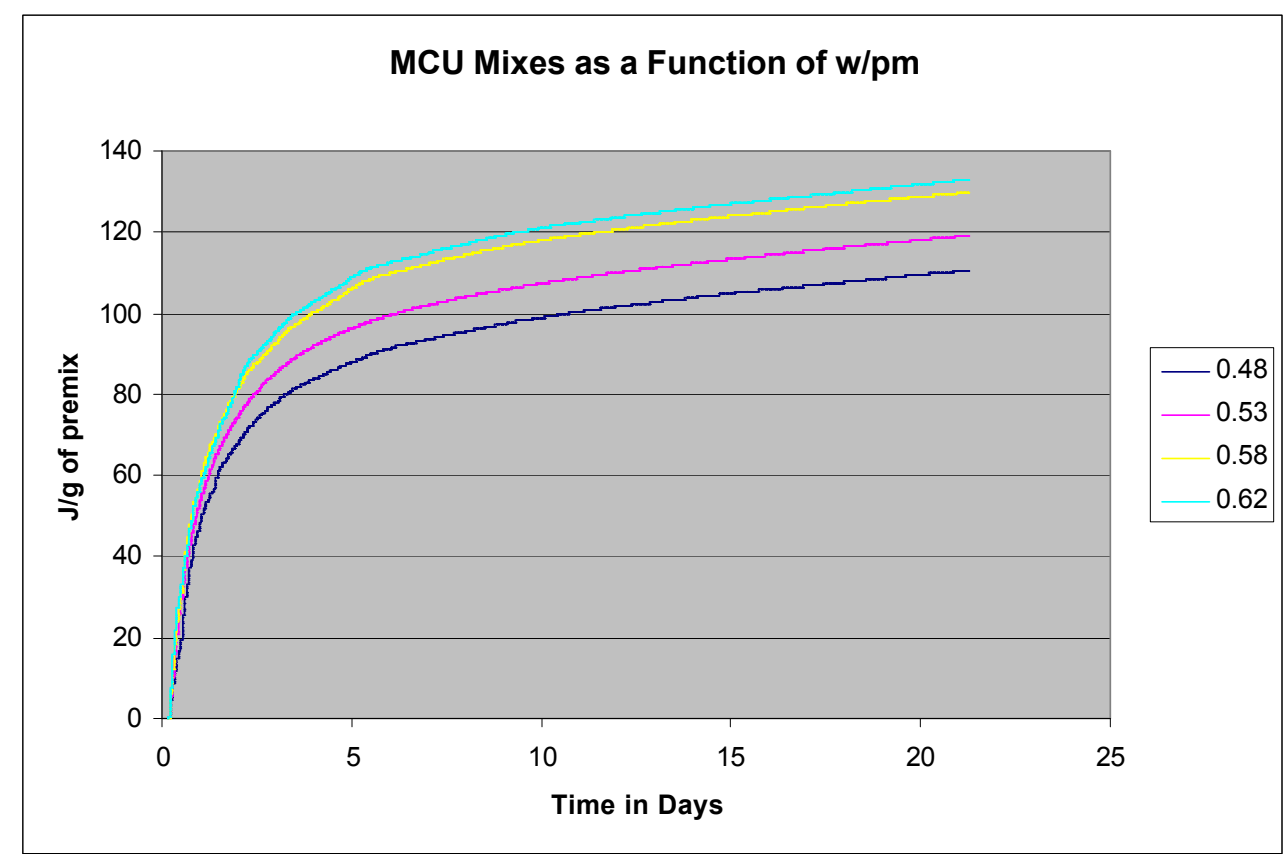

Figure 4-3 Normalized heat of hydration ( $\mathrm{J} / \mathrm{g}$ of premix) as a function of w/cm ratio for MCU and premix grouts

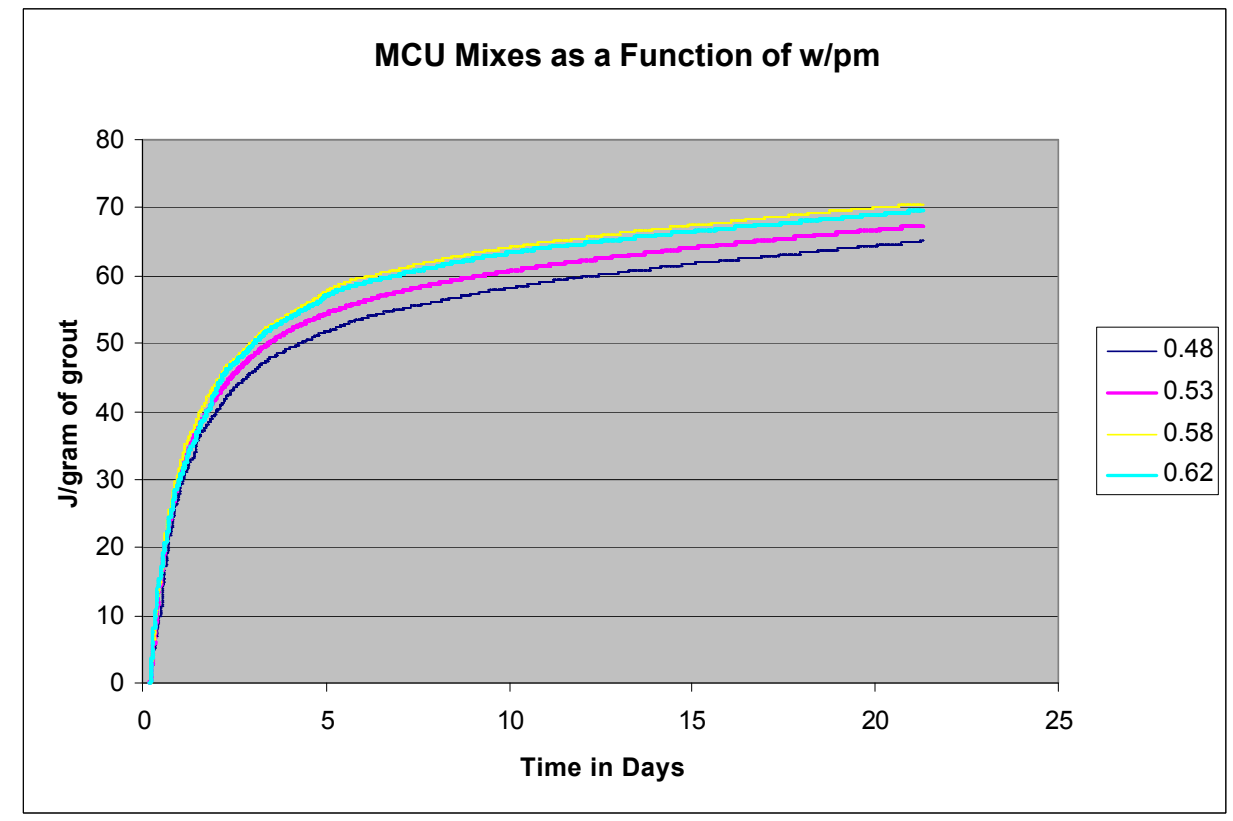

Figure 4-4 Normalized heat of hydration (J/gram of grout) as a function of w/cm ratio for MCU and premix grouts 
It may appear somewhat surprising (Figure 4-5) that the amount of heat produced per gram of premix actually increases with higher $\mathrm{w} / \mathrm{cm}$ ratios and waste loadings. However, there is more available water for hydration in the higher $\mathrm{w} / \mathrm{cm}$ mixes and a better dispersion of the particles in the DSS leading to a higher surface area available for hydration reactions. On the other hand, the heat produced per gram of grout is relatively constant as a function of waste loading. This is due to the fact that the heat produced per gram of premix at higher waste loadings is distributed over a greater inert loading of DSS.

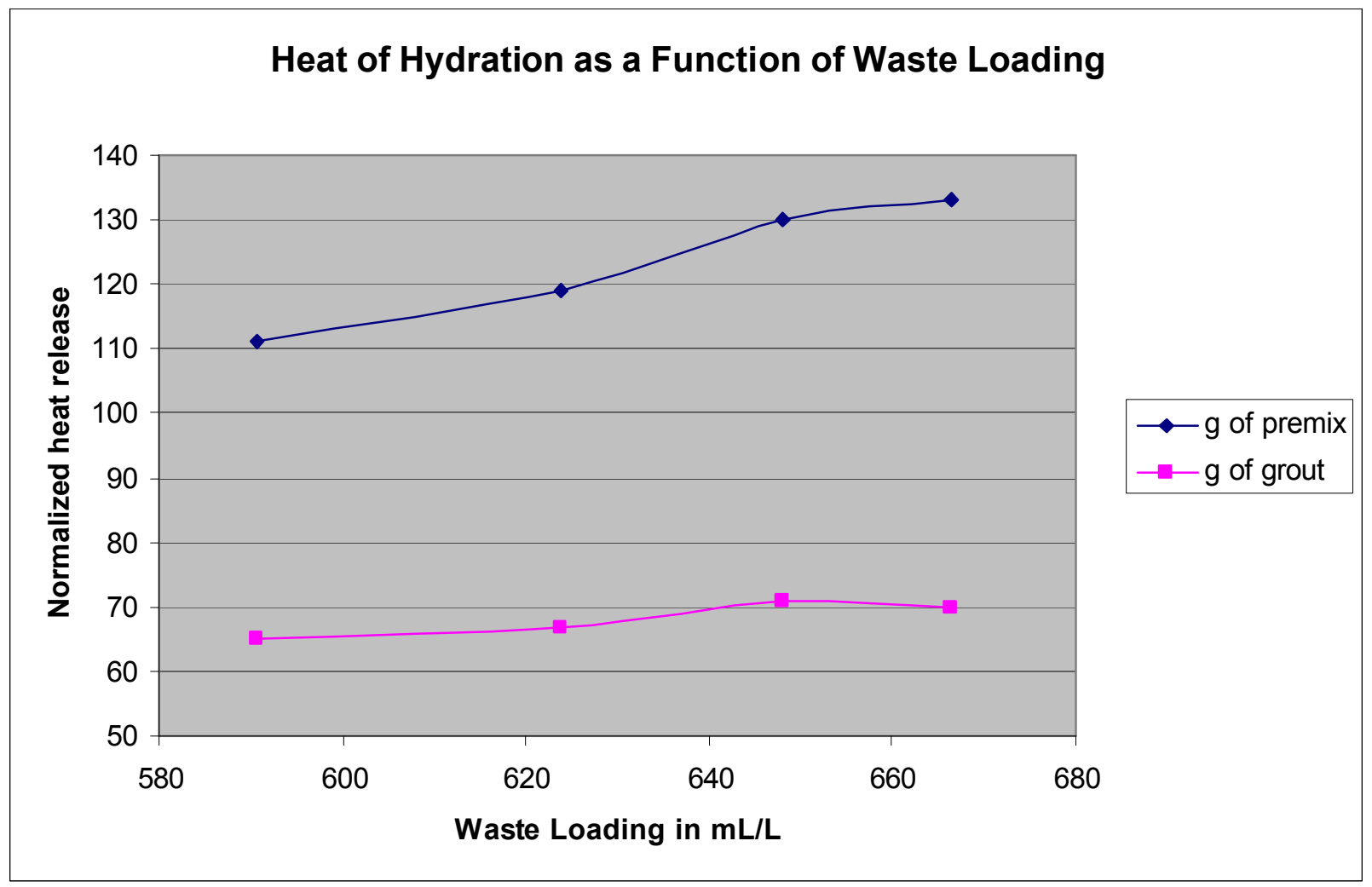

Figure 4-5 Normalized heats of hydration as a function of waste loading for MCU and premix grouts

\subsection{Waste Loading as a Function of Premix Composition for MCU Mixes}

Changing the cementitious materials composition in the premix to either $100 \%$ OPC or $100 \%$ BFS results in a greater degree of hydration and in a higher cured grout density. Consequently, the waste loading increases under these conditions to the values presented in Table 4-4. These results (all at $0.60 \mathrm{w} / \mathrm{cm}$ ratio) are from two separate mixes of the same materials made on different days and show the variability present in the results. In this case the WL was greater for OPC in MCU (709 mL/L) than the corresponding mix using BFS $(689 \mathrm{~mL} / \mathrm{L})$. Both values of 
WL are higher than MCU and premix with a WL of $653 \mathrm{~mL} / \mathrm{L}$. For these results, the only driver that determines waste loading is the cured grout density since the $\mathrm{w} / \mathrm{cm}$ ratio is constant.

Table 4-4 Waste Loading for MCU Mixes Batched Using OPC or BFS

\begin{tabular}{|c|c|c|c|c|c|c|c|c|}
\hline Simulant & Curing Time & Cementitious & Grout Density & simulant & Total & Mass Ratio & WL & Porosity \\
\hline & days & Material & g/mL & $\mathrm{g}$ & $\mathrm{g}$ & & $\mathrm{mL} / \mathrm{L}$ & \\
\hline TR421 & 107 & OPC & 1.905 & 186.9 & 400 & 0.47 & 706 & 51.2 \\
\hline TR428 & 94 & OPC & 1.922 & 186.9 & 400 & 0.47 & 712 & 52.7 \\
\hline TR420 & 107 & BFS & 1.850 & 186.9 & 400 & 0.47 & 686 & 52.9 \\
\hline TR433 & 94 & BFS & 1.868 & 186.9 & 400 & 0.47 & 692 & 53.2 \\
\hline
\end{tabular}

\subsection{Impact of Waste Loading on Number of Vaults}

The next generation of Saltstone vaults in the SDF, each cell (each vault contains two identical cells) will be cylindrical with a diameter of 150 feet and a height of about 22 feet. In the following example, the volume of Saltstone that each cell can hold was estimated at 2.7 million gallons or 10.2 million liters (Figure 4-6). Furthermore, it is assumed that there are 100 million gallons ( 380 million liters) of DSS to be processed.

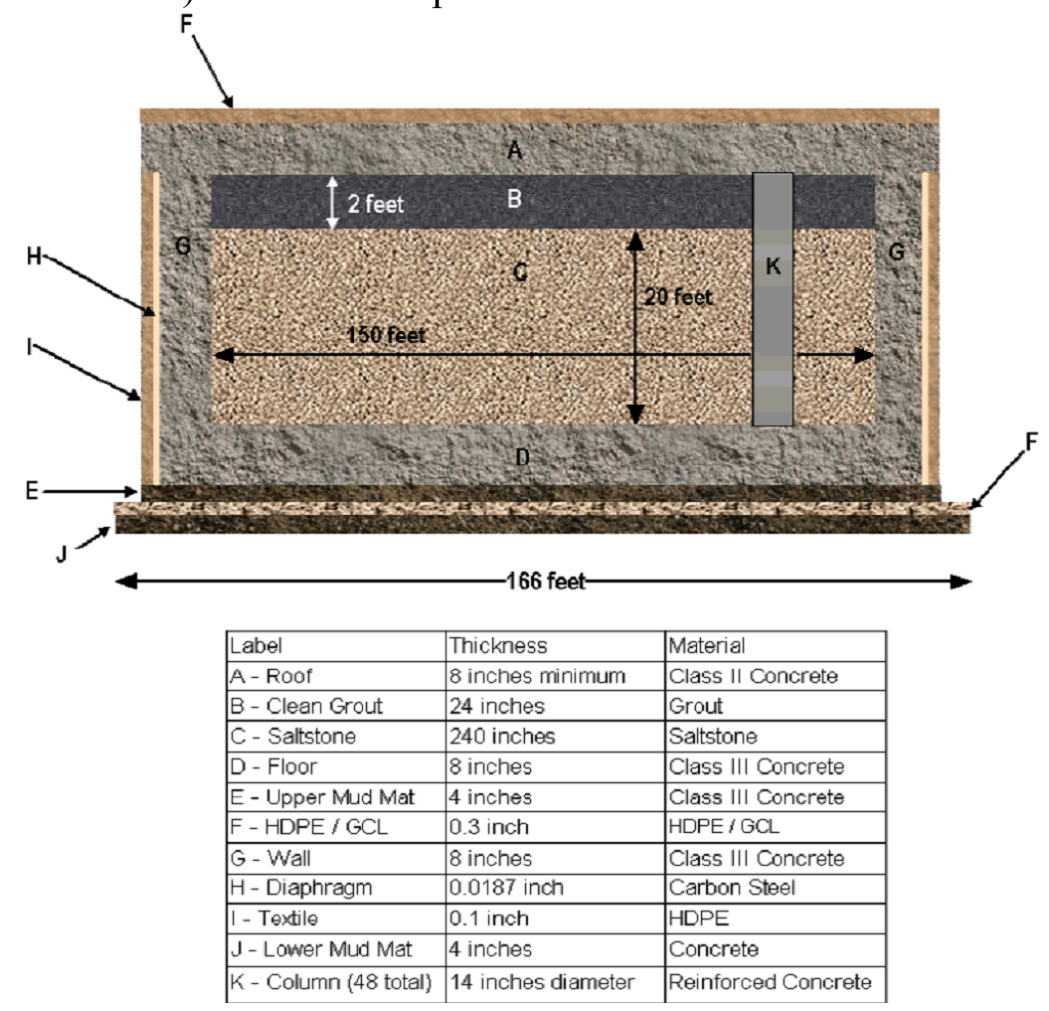

Figure 4-6 Schematic (not to scale) of current design for the next generation cells within the Saltstone vaults 
If we assume for simplicity in this example, that all of the 100 million gallons of DSS are homogeneous and represented by MCU, then we can determine the impact of a reasonable range of WL's on the total number of cells needed. Figure 4.7 shows the number of cells required as a function of WL (and w/cm ratio) for the MCU premix case. This example reveals that the impact of WL on the number of cells required over the range of 0.48 to $0.62 \mathrm{~W} / \mathrm{cm}$ ratio varies from 57 to 65 (29 to 33 vaults). The same general trend in dependence of the number of vaults as a function of WL can be made in the case where we assume all 100 million gallons to be processed at the SPF are of an SWPF DSS composition since the chemical composition of SWPF is relatively close to that of MCU.

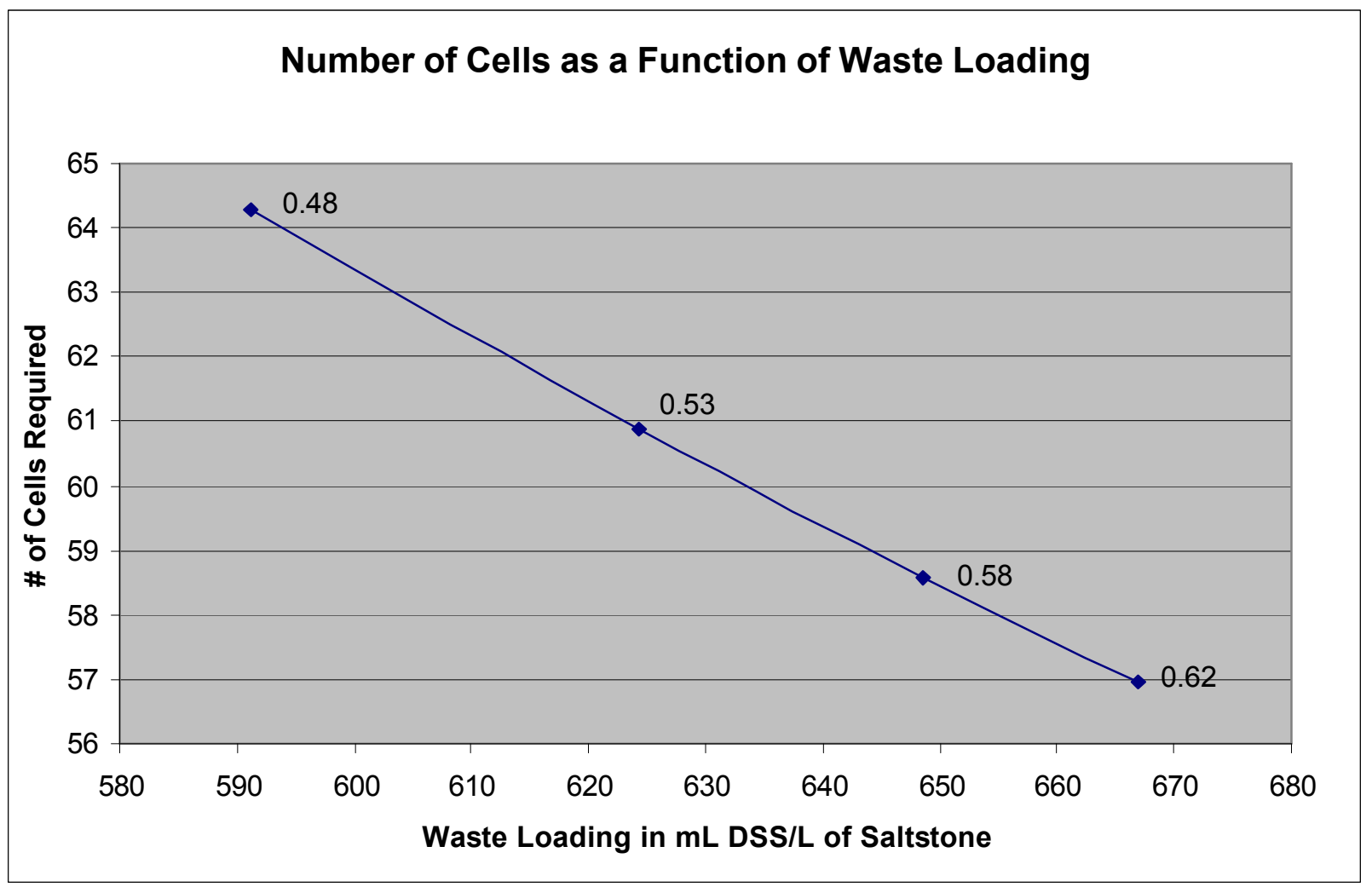

Figure 4-7 Number of cells required at the SDF as a function of waste loading for this example (the values next to the 4 points on the graph are the $\mathrm{w} / \mathrm{cm}$ ratios for each $\mathrm{mix}$ )

Higher waste loading may be achieved at $\mathrm{w} / \mathrm{cm}$ ratios greater than 0.62 provided that the $\%$ bleed volume is minor. This would result in a further reduction in the number of vaults required. However, if improved performance is required for the Saltstone waste form, a lower w/cm ratio may be necessary. 


\subsection{CONCLUSIONS}

Waste loading is a measure of the amount of waste that can be incorporated within a waste form. The value of the Saltstone waste loading ultimately determines the number of vaults that will be required to disposition all of the DSS. In this report, the waste loading is defined as the volume in milliliters of DSS per liter of Saltstone waste form.

The two most important properties that determine waste loading for Saltstone are $\mathrm{w} / \mathrm{cm}$ ratio and the cured grout density. Data were provided that show this dependence of waste loading on the $\mathrm{w} / \mathrm{cm}$ ratio for a fixed DSS composition using the current premix material (45\% BFS, $45 \%$ FA and $10 \% \mathrm{OPC})$. The impact of cured grout density on waste loading was also demonstrated. Mixes (at $0.60 \mathrm{w} / \mathrm{cm}$ ) made with MCU and either OPC or BFS have higher cured grout densities than mixes made with premix and increase the WL to $709 \mathrm{~mL} / \mathrm{L}$ for the $\mathrm{OPC}$ mix and $689 \mathrm{~mL} / \mathrm{L}$ for the BFS mix versus the value of $653 \mathrm{~mL} / \mathrm{L}$ for $\mathrm{MCU}$ in premix at $0.60 \mathrm{w} / \mathrm{cm}$ ratio.

Bleed liquid reduces the waste loading and lowers the effective $\mathrm{w} / \mathrm{cm}$ ratio of Saltstone. A method is presented (and will be used in future tasks) for correcting the waste loading and the $\mathrm{w} / \mathrm{cm}$ ratio of the mixes in the case where bleed liquid is present. For example, the DDA mix at an as-batched $0.60 \mathrm{w} / \mathrm{cm}$ ratio, when corrected for $\%$ bleed, gives a mix with a $0.55 \mathrm{w} / \mathrm{cm}$ ratio and a WL that has been reduced from 662 to $625 \mathrm{~mL} / \mathrm{L}$.

An example was provided that demonstrated the quantitative impact of WL on the number of vaults required to disposition all of the 100 million gallons of DSS available in the tanks. This calculation revealed that the number of cells required over the range of 0.48 to $0.62 \mathrm{~W} / \mathrm{cm}$ ratio (equivalent to a WL range of 591 to $666 \mathrm{~mL} / \mathrm{L}$ ) varies from 65 to 57 cells (33 to 29 vaults). The intent of this example was to show the range of variation in vaults expected due to $\mathrm{w} / \mathrm{cm}$ ratio rather than to estimate the actual number of vaults required.

There is a tradeoff between the waste loading and the processing and performance properties of Saltstone. The performance properties improve in general as the $\mathrm{w} / \mathrm{cm}$ ratio decreases. As noted above, lower w/cm ratios result in lower waste loading and consequently, a larger number of vaults. The final performance and processing requirements of Saltstone will determine the maximum waste loading achievable. Values of porosity, a performance property, were measured on the mixes and confirm the impact of changes in $\mathrm{w} / \mathrm{cm}$ ratio and in premix composition on performance. In addition, the heats of hydration of the mixes as a function of $\mathrm{w} / \mathrm{cm}$ ratio are provided. For a given w/cm ratio, higher heats of hydration generally lead to better performance of the grout waste form. On the other hand, the higher heats of hydration lead to higher temperatures in the vaults and may limit processing rates 


\subsection{PATH FORWARD}

New Saltstone formulations are currently being developed that will lead to improved performance. As part of the protocol for this effort, the waste loading for each mix will be determined as defined in this report, adjusted for bleed volume as required, and the results included in the reports for these efforts.

\subsection{REFERENCES}

[1] Scoping Studies for Development of Saltstone Variability Study, J. R. Harbour and T. B. Edwards, WSRC-RP-2005-01439, Rev. 0, 2005.

[2] Variability Study for Saltstone, J. R. Harbour, T. B. Edwards, E. K. Hansen and V. J. Williams, WSRC-TR-2005-00447, October 2005.

[3] Effect of Increased Aluminate Concentrations on Properties of Saltstone Mixes, J. R. Harbour, T. B. Edwards, E. K. Hansen and V. J. Williams, WSRC-STI-2007-00506, Rev. 0, 2007.

[4] Saltstone Variability Study-Measurement of Porosity, J. R. Harbour, V. J. Williams, T. B. Edwards, R. E. Eibling, and R. F. Schumacher, WSRC-STI-2007-00352, Rev. 0, 2007.

[5] Heat of Hydration of Saltstone Mixes - Measurement by Isothermal Calorimetry, J. R. Harbour, V. J. Williams and T. B. Edwards, WSRC-STI-2007-00263, Rev. 0, 2007. 